\title{
Effect of religious teachings on social capital in Malaysia
}

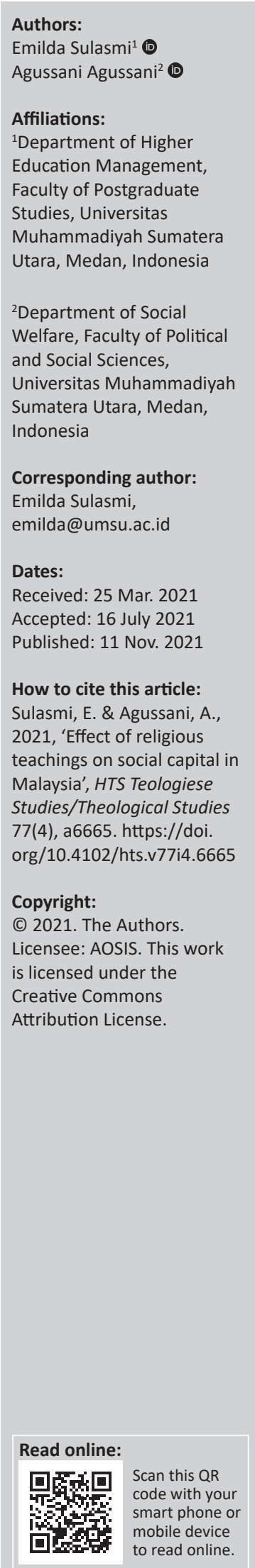

As one of the key concepts of social sciences that constitutes one of the cultural foundations of modern societies along with elements such as rationality and rule of law, social capital has a special place amongst social science scholars. This article claimed that religion and its teachings have received less attention as an important factor in social capital. Creating social capital by neglecting religious teachings is very difficult and useless because religion can play a significant role in creating some of the most important elements of social capital because of its unique characteristics. This article aimed to study the effect of religious teachings on social capital. Therefore, 2000 Kuala Lumpur citizens were investigated by simple random sampling and the collected data were evaluated by Linear Structural Relations (LISREL) after measuring the current level of religious teachings and social capital in the Statistical Package for the Social Sciences (SPSS) version 16. Data analysis indicated a positive effect of religious teachings on social capital $(P=0.68 ; T=4.92)$. With regard to the relationship of social capital with religion and according to the obtained findings, the article described and explained the situation of sociological relationship of Islam with social capital in Islamic society.

Contribution: This article provided further insight into the relationship between religious teachings and social capital in a Muslim country.

Keywords: religion; religiosity; religious teachings; social capital; Malaysia.

\section{Introduction}

In addition to human and economic capital, recently another capital called social capital has attracted more attention. Social capital, or the spiritual element of a community, is a historical heritage that, by encouraging individuals to cooperate and participate in social interactions, can succeed in solving more of the problems in that community, and make it possible to move towards rapid economic, political and cultural growth and development, etc. (Story 2013). In fact, social capital can be considered as a part of national wealth along with economic and human capital, which is considered as a suitable platform for exploiting human and physical capital and a path to success (Ebstyne King \& Furrow 2008). Many groups, organisations and human societies have been able to succeed without economic capital and relying solely on human and social capital, whilst no human group can perform useful and purposeful actions without social capital (Tenzin, Otsuka \& Natsuda 2015). On the other hand, social capital gives meaning to one's life and makes life easier and more enjoyable. In general, it can be argued that the more social capital a nation has, the happier and richer that nation will be. Some of the dimensions, elements and forms of social capital - sometimes referred to as social values - include trust, honesty, understanding, self-health, empathy, friendship, solidarity and sacrifice (Kawachi, Subramanian \& Kim 2008). These elements are formed through information flows such as job-related training, exchange of ideas, exchange of information, norms of social media transactions, popular participation, self-help groups and altruism, and the spirit of collectivism versus individualism between members of social networks, so that the footprint of this discussion can also be seen in the relations of all social groups such as religious (mosque church), sports (clubs), civic (associations, unions, parties and independent media), educational (schools, universities) and in neighborhood, friendly, professional and family relationships (Coleman 1988).

Religious teachings in their doctrinal, moral and jurisprudential elements lead to the emergence and strengthening of social capital in the form of intragroup in the first stage and extra group in the next stage (Wilson 1982). Social capital has been considered by many thinkers as one of the most important social issues with the potential of popular power. According to many experts, people's religiosity is one of the key factors in increasing social capital in society (Candland 2001). Considering the approval of most components of social capital in Islam, it is necessary to evaluate the effect of religiosity on social capital. Religion, as a transcendent value, obviously causes the formation of certain spirits and practices in the social life of individuals, which are evident for everyone. One of the serious consequences of religion in society may be the strengthening of 
social relations of individuals (Lichterman 2008). Religion, as one of the cultural aspects, focuses on activities and actions that, according to its followers, bring ultimate meaning to life and lead to the final solution of problems (Koenig 2009). This is one of the building blocks of social capital functions. Individuals, depending on their religion, may be a source of participation, such as attending and participating in the affairs of mosques, churches and places of worship; religion can even form a network of trust between individuals that is essential for business relationships and economic exchange (Muller \& Ellison 2001). Accordingly, the relationship between the social institutions of religion and the communication networks of individuals has attracted further attention of many sociologists. The consequences that those institutions send to individuals in society, the systems they provide and the social networks they create, can all act as the source and basis for the formation of social capital. As ethnic ties and kinship have played an important role in the past as a measure of the solidarity and unity of societies, these criteria have lost their function and other links have replaced these human relationships currently because of the evolution of societies, the prevalence of modern values, diversity of life, migration and so on (Berger 2011).

In this regard, this article seeks to answer the question of how religious teachings affect social capital. Social capital is one of the most important characteristics of all societies, whose existence is essential in all societies. This feature can play a key role in the development and progress of human societies. Undoubtedly, social capital is not related to the concept of religion and religiosity. According to research, in societies where the role of religion is more prominent, such societies naturally have higher social capital. Social capital is considered as a resource that individuals, groups and communities can use to achieve the desired results and it is a concept that is often applied by social analysts to describe a wide range of social processes. Now the researcher's question is to find an appropriate answer to what is the relationship between religious teachings and social capital amongst the citizens of Kuala Lumpur (Malaysia) in 2020.

\section{Religiosity and its relationship with social capital}

Religion is considered as an external and independent phenomenon, whilst religiosity refers to the acceptance of religion by human beings. In fact, religiosity is a human trait and state to which religion belongs. It should be observed that studies on the operational definition of religiosity are based on two trends: the sociological or social tradition and the psychological or individual tradition. There are two main approaches to the study of religion amongst social scientists: firstly, an approach that has affirmed the element of rituals and religious practices (ed. Smidt 2003); in this view, religious practices, such as rituals and ceremonies, are of fundamental importance in religiosity, and individuals should pay close attention to this element in order to understand the extent of religiosity; and secondly, a group that has paid special attention to the semantic, subjective and symbolic aspects of religion, and considered it a human phenomenon (Oman \& Reed 1998). In this view, practices and rituals are subdivisions of symbols and meanings and their role is to point out the meanings crystallised in culture. Religion gives meaning to human life and frees it from meaninglessness; other phenomena are only symbolic. These views suggest that religiosity has different elements and degrees and each thinker has emphasised an aspect of it. Some religious scholars have tried to analyse the various elements of religion and to combine religiosity for the degree of religiosity and to develop a multidimensional view of religiosity (Bruce 1999).

It is worth noting that there are numerous models for measuring religiosity - both by Western theologians and Eastern scholars. It can be argued that religion can play an effective role in cohesion, facilitating socialisation, defining social values and norms, strengthening shared emotions, strengthening the foundations of social control, increasing peace of mind, strengthening team spirit, cooperating and establishing social actions based on trust and honesty, consolidating a sense of commitment, expanding and strengthening active participation, etc. Once the relationship between religion and social capital is clarified, the question arises as to how and in what ways religion can be effective in institutionalising social capital. In answer to this question, it should be observed that religious institutions could be effective in the formation of social capital through at least three sets of mechanisms.

Religious institutions promote theidea that positiverelationships between family members and the community are commendable. Religious institutions use mechanisms through which they provide formal support to individuals and families. Churches and other religious organisations organise most activities to strengthen interaction and positive relationships amongst members of the community. On the one hand, they spend time with everyone by attending religious centres, and on the other hand, they provide counselling, education, etc. by setting up family camps and strengthening the opportunities for bonding between people. Another set of mechanisms includes the role of religion in the formation and subordination of social relationships by connecting friends and family members in the same social group, that is, the connection and correlation between the components and elements of a set and the role of religion in this connection (Ebstyne King 2003). It seems that family members who participate in similar religious institutions are likely to have a series of social relationships with other members of that religious institution. Religion strengthens the social network subordination of parents and children, so that it increases social relations and improves more positive kinship relations (Regnerus 2003:394).

\section{Social capital}

Social capital should be considered as an important link between the characteristics and immediate social context of individual (Ebstyne King \& Furrow 2008). The importance of social capital lies in its potential capacity to link independent individuals to each other, so that it can turn stakeholders who have limited social knowledge of each other and have the least 
sense of reciprocity into individuals with common interests (ed. Smidt 2003). Social capital can be defined as the resources available within social structures such as trust, norms of reciprocity and common goals that prepare individuals to engage in collective action (Kawachi \& Berkman 2001). Social capital is a set of the physical or non-physical resources available to an individual or group that has a relatively longlasting network of institutionalised relationships with mutual and respected acquaintances (Field 2004). According to Bourdieu, the concept of social capital is not only an important modifier for the normative, empirical and intrinsic readings of this concept but also a better sociological definition of this concept. In fact, Bourdieu states that social capital means a kind of social relation rather than a norm. In other words, social capital is the cultural context resulting from social construction that is organised and formulated in direct relation to the habits of individuals and the cultural field following social actions (Bourdieu 1986).

Coleman also uses social role to define social capital and provides a functional definition of social capital. Accordingly, social capital is not a single object, but a variety of issues, all of which include an aspect of a social construct that facilitates the specific actions of individuals within the structure. Social capital, like other forms of capital, makes it possible to achieve certain goals in the absence of which it would not be achievable (Coleman 1994).

According to Putnam, social capital is a set of resources generated through relationships between individuals, social networks and reciprocal norms and trust. Social capital expresses the characteristics of an organisation or social structure. The features such as trust, norms and networks make society efficient in coordinated activities and make it possible to perform great affairs that cannot be achieved without social capital. Putnam (1993) considers the basic elements of social capital as mutual commitment and trust, shared values and norms, sense of belonging, honesty and social interactions.

Like Putnam, Fukuyama speaks of the existence of norms and values in defining this concept. Fukuyama considers informal norms and values in a group and expresses accordingly: social capital can simply be defined as the existence of a certain set of informal norms or values in which members of a group to which cooperation is permitted share; however, participation in values and norms does not in itself produce social capital, because they may be negative values. In fact, Fukuyama believes that trust is an expectation based on shared norms and honesty and cooperative behaviours (Fukuyama 2000).

Social capital is one of the most recent types of capital that has been considered by many researchers today. Social capital is not a set of social infrastructure institutions, but a connecting link of individuals in the form of institutions, networks and organisations. Social capital has no individual ownership, it belongs to all members of the group or association and does not decrease if consumed, but may even increase. Social capital is generated only within a group, association or social network. Cohen and Prusak argued that social capital consists of active relationships between individuals that include trust, mutual understanding, shared values and behaviours that connect members of human networks and communities and enable collaboration. Social capital strengthens cooperation, commitment, information sharing and trust. It also promotes real participation in the organisation, which in turn leads to greater success and effectiveness (Cohen \& Prusak 2002).

Social capital paves the way for access to and use of other resources of the organisation. In fact, social capital is an intangible asset in the organisation that establishes an effective network relationship. One of the effects of social capital is to increase the productivity of organisational labour. In business organisations, social capital is an important source of productivity. To get things done, workers and professionals need to apply the advice and support of others beyond the hierarchical structure of the company (Alguezaui \& Filieri 2010).

\section{Social capital elements}

As social capital is a complex and multidimensional concept in social capital literature, different types of elements can be observed. Structural element of social capital refers to the general pattern of relationships in the society. This element is the level of communication of people with each other. The structural element of social capital includes existing links and refers to the general pattern of interpersonal contacts, that is, who you access and how.

Relationship element of social capital covers the nature of relationships in an organisation. In other words, whilst the structural element focuses on whether employees are related to each other in an organisation, the relationship element focuses on the nature and quality of these relationships, for example, 'whether or not these relationships are characterised by trust, intimacy, love and the like?' (Bolino, Turnley \& Bloodgood 2002). Cognitive element of social capital includes the degree of employee participation within a social network in a shared perspective or understanding, and, like the relationships element, it addresses the nature of interpersonal communication in an organisation (Nahapiet \& Ghoshal 1998).

\section{Methods}

The present study is an applied research in terms of purpose and is a descriptive-causal (non-experimental) research in terms of data collection and method of review and analysis. The researcher tries to answer a real problem and question during a research process.

The simple random sampling method was used in this study; thus, standard questionnaires were applied to measure the variables of religious teachings and social capital amongst 2000 Muslim citizens of Malaysia in 2020. To measure social capital, 15 questions extracted from the study of Nahapiet and Ghoshal (1998) were used as dependent variables in three elements (structural, cognitive and relational). The 
20-items questionnaire developed by Krauss et al. (2005) was exploited to measure the religiosity of citizens.

The reliability of the questionnaire was assessed through composite reliability $(\mathrm{CR})$ and construct validity. The $\mathrm{CR}$ value above 0.7 for each variable indicates appropriate internal stability for the measurement model, and the CR value below 0.6 indicates a lack of reliability; this value is 0.834 for religious teachings and 0.874 for social capital. The validity of the questionnaire was also assessed through convergent validity by average variance extracted (AVE). The AVE shows the correlation of a structure with its indices, so the higher this correlation, the greater the fit. The AVE value above 0.5 indicates acceptable convergent validity; this value was 0.641 for religious teachings and 0.684 for social capital. After distributing the questionnaires amongst the citizens of Kuala Lumpur, 1834 questionnaires were deemed appropriate and entered into statistical analysis. The goodness of fit in construct validity also confirms the validity of research model as Goodness of Fit Index (GFI) and Adjusted Goodness of Fit Index (AGFI) are 0.90 and 0.91 , respectively; $P$-value is 0.000 and Root Mean Square Error of Approximation (RMSEA) is 0.73.

The results of descriptive statistics show that $62 \%$ of the statistical sample were men and $38 \%$ were women; $42 \%$ of people were 30 years old and younger, 39\% of people were between 30 and 45 years and $23 \%$ of people were older than 45 years and $57 \%$ of people were married and $43 \%$ were single.

\section{Results}

The first hypothesis of the research is how favourable (appropriate) the conditions of the research variables are. To answer this question, we examine the status (favourable or unfavourable) of variables and their elements. This was achieved by One-sample $t$-test. The results of this test help to measure the level of each of the indicators and elements related to spiritual intelligence, organisational justice, job satisfaction and organisational citizenship behaviour. The hypotheses are tested as follows:

$\mathrm{H} 0: \mu=3$

Elements / indices do not differ from the mean value

$\mathrm{H} 1: \mu \neq 3$

Elements / indices differ from the mean value

Considering that a 5-point Likert scale was used in the questionnaire, the test value of 3 (moderate level) has been applied. In examining the status of components, it should be observed that the favourable status is a condition in which the mean score of the element is greater than 3 , and in contrast, the unfavourable status is a condition in which the mean score of the element is less than 3. In the analysis of indicators related to religious teachings and social capital, all indicators have a significance level of less than 0.05 , thus, for the given indicators, hypothesis zero is rejected and its status is significantly different from the mean value of 3 . For these indicators, because of the positive value of $T$-statistic, their value is higher than the mean value of the population and its status is estimated to be appropriate (Tables 1 and 2).

In addition, Figures 1 and 2 illustrate the test results of the research hypotheses in the form of structural equation modelling and $T$-value model in LISREL.

Table 3 also shows the results of the research hypotheses test, which confirmed or rejected the relevant hypothesis amongst Muslim citizens of Kuala Lumpur in 2020. As P is positive and $T$-value is more than 1.96 , research hypothesis is confirmed.

\section{Discussion}

The rapid and increasing progress of contemporary man in various fields of science has given rise to the means by which the standard of living has changed over the past. The world of electronics has enhanced the quality of human life in the fields of business and economics, services,

TABLE 1: Descriptive statistics of research.

\begin{tabular}{lcccc}
\hline Variables & $\boldsymbol{N}$ & Mean & SD & $\begin{array}{c}\text { Standard } \\
\text { error mean }\end{array}$ \\
\hline Structural element & 1834 & 3.9816 & 0.48077 & 0.03264 \\
Network relationships & 1834 & 4.2151 & 0.45766 & 0.03107 \\
Relationship element & 1834 & 4.1413 & 0.38049 & 0.02583 \\
Social capital & 1834 & 4.1126 & 0.33265 & 0.02258 \\
Religious teachings & 1834 & 4.0806 & 0.32072 & 0.02177 \\
\hline
\end{tabular}

SD, standard deviation.

TABLE 2: One-sample $t$-test of research.

\begin{tabular}{|c|c|c|c|c|c|c|}
\hline \multirow[t]{3}{*}{ Variables } & \multicolumn{6}{|c|}{ Test value $=\mathbf{3}$} \\
\hline & \multirow[t]{2}{*}{$t$} & \multirow[t]{2}{*}{ Df } & \multirow[t]{2}{*}{$\begin{array}{l}\text { Significance } \\
\text { (2-tailed) }\end{array}$} & \multirow[t]{2}{*}{$\begin{array}{c}\text { Mean } \\
\text { difference }\end{array}$} & \multicolumn{2}{|c|}{$\begin{array}{l}95 \% \text { confidence interval } \\
\text { of the difference }\end{array}$} \\
\hline & & & & & Lower & Upper \\
\hline $\begin{array}{l}\text { Structural } \\
\text { element }\end{array}$ & 30.075 & 1833 & 0.000 & 0.98157 & 0.9172 & 1.0459 \\
\hline $\begin{array}{l}\text { Network } \\
\text { relationships }\end{array}$ & 39.109 & 1833 & 0.000 & 1.21505 & 1.1538 & 1.2763 \\
\hline $\begin{array}{l}\text { Relationship } \\
\text { element }\end{array}$ & 44.187 & 1833 & 0.000 & 1.14132 & 1.0904 & 1.1922 \\
\hline Social capital & 49.272 & 1833 & 0.000 & 1.11265 & 1.0681 & 1.1572 \\
\hline $\begin{array}{l}\text { Religious } \\
\text { teachings }\end{array}$ & 49.632 & 1833 & 0.000 & 1.08060 & 1.0377 & 1.1235 \\
\hline
\end{tabular}

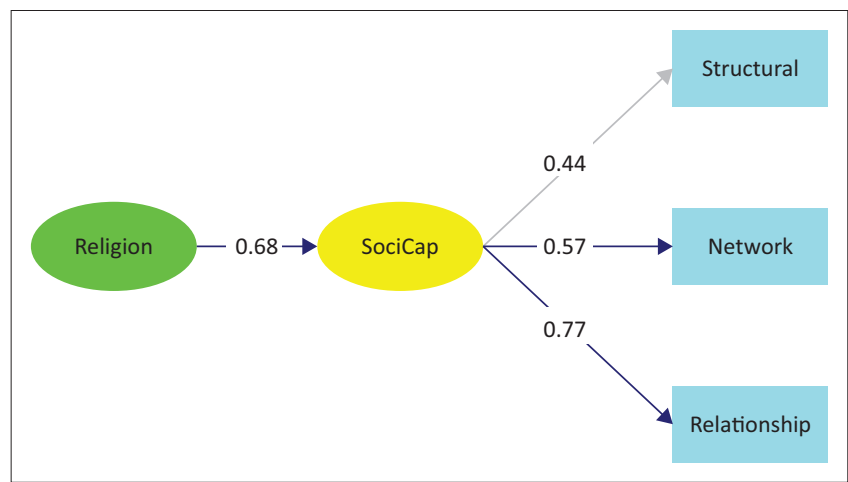

FIGURE 1: Structural equation modelling of research. 


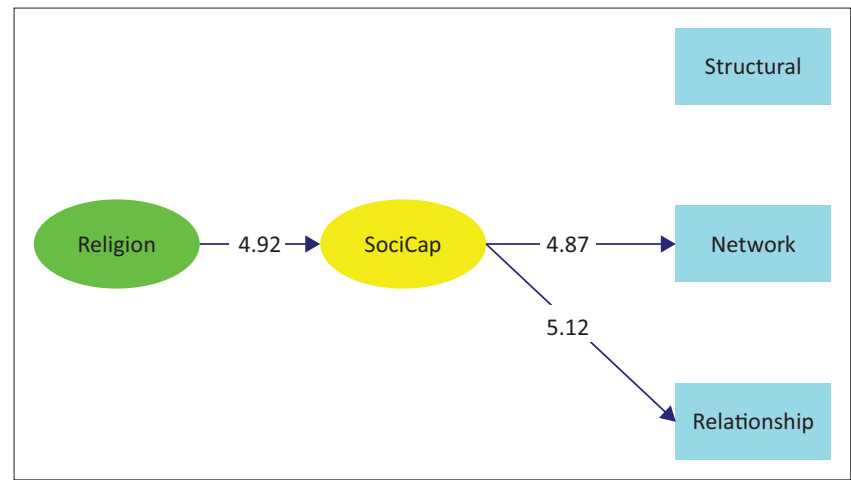

FIGURE 2: $T$-value model of research.

TABLE 3: Hypothesis test results.

\begin{tabular}{lccc}
\hline Hypothesis & $\boldsymbol{P}$ & $\boldsymbol{T}$ & Results \\
\hline Religious teachings $\rightarrow$ Social capital & 0.68 & 4.92 & Confirmed \\
\hline
\end{tabular}

healthcare, industry, education and communications. The establishment of global economic and non-economic organisations of the Commonwealth of Independent States has removed the national borders of countries and made it possible to achieve human relations in the common global markets. At the same time, however, these scientific advances have created deep divisions in societies and provided many platforms for anxiety and worry of the contemporary man. In practice, this puts human beings in a position where class systems and maximum social poverty stand out approximating massive wealth and minimal concentrated power. This article claims that the source of worries and anxieties is the pantheism of contemporary man and his alienation with religious teachings, which is surrounded by an aura of vague image of the salvation of his living space. The priority of today is in religiosity and thinking of the teachings in the Qur'an is the most basic instruction that if contemporary man acts on it and achieves religious morality by changing his life and spiritual conduct, he can find a way out of his new worries and expand his social capital in society.

Social capital is affected by several factors. One of the influential factors being less considered independently in previous researches is religiosity; and researches in this field have faced a gap in this regard. One of the reasons for ignoring the influence of religious teachings can be related to the position of this concept as a structure in social studies, that is, because of the complexity and high degree of abstraction of the concept, it is considered as a dependent variable. Therefore, the problem statement of the research has been around the axis that this research has been conducted amongst Muslim citizens, and the extent to which Islamic religious teachings has been able to strengthen their social capital. In general, it can be said that social capital is a capacity, social essence or informal norm that promotes cooperation between individuals and institutions of a society. Every social network, in order to achieve its goals, in addition to knowledgeable and experienced people and facilities, needs factors such as trust, commitment and responsibility, which are considered as social capital. As the results of the present study showed, the citizens of Kuala Lumpur, according to Table 1, perceive acceptable levels of religious teachings and social capital in their community. Meanwhile, according to Figures 1 and 2, religious teachings have a positive and significant effect on social capital of Muslim citizens $(P=0.68 ; T=4.92)$.

The Holy Qur'an considers education as one of the goals of the mission of the prophets, and says Allah certainly favoured the faithful when he raised up amongst them an apostle from amongst themselves to recite to them his signs and to purify them and teach them the Book and wisdom, and earlier they had indeed been in manifest error (Surah Ali 'Imran, Ayat 164).

Another verse, in addition to teaching the Book and Wisdom, refers to teaching, 'what they did not know', and says:

Just as we have sent amongst you a messenger from yourselves reciting to you our verses and purifying you and teaching you the Book and wisdom and teaching you that which you did not know. (Surah Al-Baqarah, Ayat 151)

Islam emphasises the value of teaching any useful science, but not all sciences have the same value. The value of religious sciences is not comparable to other sciences. Teaching religious rules and teachings is the necessary precondition and condition for freeing man from the fire of Hell and attaining eternal happiness. Hence, in the life of the divine prophets, especially the prophet of Islam, it has been given a lot of value; therefore, religious teachings will have many positive results that deserve special attention of Islamic religious leaders and citizens of society.

\section{Conclusion}

As one of the vital ideas of sociologies, that establishes one of the social establishments of present day cultures alongside components such as soundness and law and order, social capital has an uncommon spot amongst sociology researchers. This article asserted that religion and its lessons have gotten less consideration as a significant factor in friendly capital, whilst making social capital by dismissing strict lessons is troublesome and pointless in light of the fact that religion can assume a huge part in making the absolute most significant components of social capital because of its one of a kind attributes. Thus, 2000 Kuala Lumpur residents were researched and the gathered information was assessed by LISREL in the wake of estimating the momentum level of strict lessons and social capital in SPSS. Information investigation showed a constructive outcome of strict lessons on friendly capital $(P=0.68 ; T=4.92)$. As to the relationship of social capital with religion and as per the acquired discoveries, the article portrayed and clarified the circumstance of sociological relationship of Islam with social capital in Islamic culture. 


\section{Acknowledgements Competing interests}

The authors declare that they have no financial or personal relationships that may have inappropriately influenced them in writing this article.

\section{Authors' contributions}

Both authors contributed equally to this article.

\section{Ethical considerations}

This article followed all ethical standards for research without direct contact with human or animal subjects.

\section{Funding information}

This research received no specific grant from any funding agency in the public, commercial or not-for-profit sectors.

\section{Data availability}

Data sharing is not applicable to this article as no new data were created or analysed in this study.

\section{Disclaimer}

The views and opinions expressed in this article are those of the authors and do not necessarily reflect the official policy or position of any affiliated agency of the authors.

\section{References}

Alguezaui, S. \& Filieri, R., 2010, 'Investigating the role of social capital in innovation: Sparse versus dense network', Journal of Knowledge Management 14(6), 891-909.

Berger, P.L., 2011, The sacred canopy: Elements of a sociological theory of religion, Open Road Media, New York, NY.

Bolino, M.C., Turnley, W.H. \& Bloodgood, J.M., 2002, 'Citizenship behavior and the creation of social capital in organizations', Academy of Management Review 27(4), 505-522. https://doi.org/10.5465/amr.2002.7566023

Bourdieu, P., 1986, 'The forms of capital', in J. Richardson (ed.), Handbook of theory and research for the sociology of education, pp. 241-258, Greenwood, Westport, CT.

Bruce, S., 1999, Religion and modernization: Sociologists and historians debate the secularization thesis, Clarendon Press, Oxford.
Candland, C., 2000, 'Faith as social capital: Religion and community development in southern Asia', Policy Science 33(3-4), 355-374.

Cohen, D. \& Prusak, L., 2002, In good company: How social capital makes organizations work, Harvard Business School Press, Boston, MA.

Coleman, J.S., 1988, 'Social capital in the creation of human capital', American Journa of Sociology 94, S95-S120. https://doi.org/10.1086/228943

Coleman, J.S., 1994, Foundations of social theory, Harvard University Press, Cambridge, MA.

Ebstyne King, P. \& Furrow, J.L., 2008, 'Religion as a resource for positive youth development: Religion, social capital, and moral outcomes', Psychology of Religion and Spirituality S(1), 34-49. https://doi.org/10.1037/1941-1022.S.1.34

Ebstyne King, P., 2003, 'Religion and identity: The role of ideological, social, and spiritual contexts', Applied Developmental Science 7(3), 197-204. https://doi. org/10.1207/S1532480XADS0703_11

Field, J., 2004, Social capital, Routledge, London.

Fukuyama, F., 2000, Social capital and civil society: IMF Working Paper WP/00/74, International Monetary Fund, Washington, DC

Kawachi, I. \& Berkman, L.F., 2001, 'Social ties and mental health', Journal of Urban Health 78(3), 458-467. https://doi.org/10.1093/jurban/78.3.458

Kawachi, I., Subramanian, S.V. \& Kim, D., 2008, 'Social capital and health', in I. Kawachi, S.V. Subramanian \& D. Kim (eds.), Social capital and health, pp. 1-26, Springer, New York, NY.

Koenig, H.G., 2009, 'Research on religion, spirituality, and mental health: A review', The Canadian Journal of Psychiatry 54(5), 283-291. https://doi. org/10.1177/070674370905400502

Krauss, S.E., Hamzah, A.H., Suandi, T., Noah, S.M., Mastor, K.A., Juhari, R. et al., 2005, 'The Muslim religiosity-personality measurement inventory (MRPI)'s religiosity measurement model: Towards filling the gaps in religiosity research on Muslims', Pertanika Journal of Social Sciences \& Humanities 13(2), 131-145. https://doi. Pertanika Journal of Social

Lichterman, P., 2008, 'Religion and the construction of civic identity', American Sociological Review 73(1),83-104. https://doi.org/10.1177/000312240807300105

Muller, C. \& Ellison, C.G., 2001, 'Religious involvement, social capital, and adolescents' academic progress: Evidence from the National Education Longitudinal Study of 1988', Sociological Focus 34(2), 155-183. https://doi.org/10.1080/00380237.200 1.10571189

Nahapiet, J. \& Ghoshal, S., 1998, 'Social capital, intellectual capital, and the organizational advantage', Academy of Management Review 23(2), 242-266. https://doi.org/10.5465/amr.1998.533225

Oman, D. \& Reed, D., 1998, 'Religion and mortality among the community-dwelling elderly', American Journal of Public Health 88(10), 1469-1475. https://doi. org/10.2105/AJPH.88.10.1469

Putnam, R., 1993, 'The prosperous community: Social capital and public life', The American Prospect 13(4), 35-42.

Regnerus, M.D., 2003, 'Religion and positive adolescent outcomes: A review of research and theory', Review of Religious Research 44(4), 394-413. https://doi. org/10.2307/3512217

Smidt, C.E. (ed.), 2003, Religion as social capital: Producing the common good, Baylor University Press, Waco, TX.

Story, W.T., 2013, 'Social capital and health in the least developed countries: A critical review of the literature and implications for a future research agenda', Global Public Health 8(9), 983-999. https://doi.org/10.1080/17441692.2013.842259

Tenzin, G., Otsuka, K. \& Natsuda, K., 2015, 'Can social capital reduce poverty? A study of rural households in Eastern B hutan', Asian Economic Journal 29(3), 243-264. https://doi.org/10.1111/asej.12057

Wilson, B.R., 1982, Religion in sociological perspective, Oxford Press, Oxford. 